\title{
Habitat et parenté : essai d'analyse combinatoire entre différentes pratiques sociales des Birmans
}

\section{François Robinne}

\section{(2) OpenEdition}

1 Journals

Édition électronique

URL : https://journals.openedition.org/tc/669

DOI : $10.4000 /$ tc.669

ISSN : 1952-420X

Éditeur

Éditions de l'EHESS

\section{Édition imprimée}

Date de publication : 1 mai 1993

ISSN : 0248-6016

\section{Référence électronique}

François Robinne, « Habitat et parenté : essai d'analyse combinatoire entre différentes pratiques sociales des Birmans », Techniques \& Culture [En ligne], 19|1993, mis en ligne le 10 janvier 2006, consulté le 29 septembre 2022. URL : http://journals.openedition.org/tc/669 ; DOI : https://doi.org/ $10.4000 /$ tc. 669

Ce document a été généré automatiquement le 29 septembre 2022.

Tous droits réservés 


\section{Habitat et parenté : essai d'analyse combinatoire entre différentes pratiques sociales des Birmans}

François Robinne 